\title{
Globalization and Chinese higher education
}

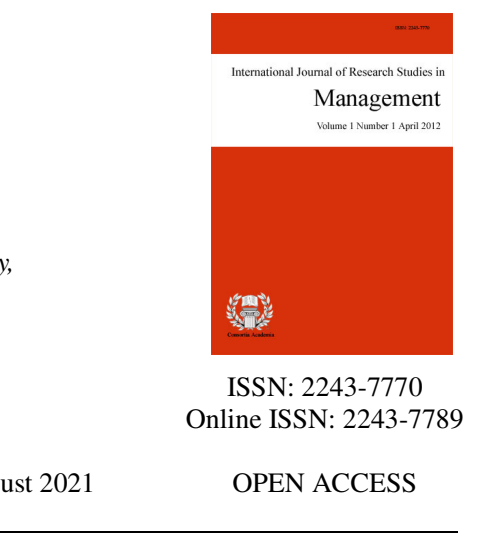

Kamala, Kandi

Government Degree College for Women (Autonomous) Begumpet, (Affiliation) of Osmania University, Hyderabad, Telangana State, India (Kamala.ranu@gmail.com)

Kamalakar, Gedam $\bowtie<$

Osmania University, Hyderabad, Telangana State, India (kamalakarou@gmail.com)

Received: 24 July 2021
Available Online: 16 August 2021

Revised: 13 August 2021

Accepted: 16 August 2021

DOI: $10.5861 /$ ijrsm.2021.m034

\section{Abstract}

The cross line movement according to the two labor and products is the thing to take care of in the present worldwide economy. Worldwide exchange labor and products has for some time been a standard, for different advantages that gather from it. There have been numerous respective and multilateral arrangements comparable to cross line exchange dealings. The development of administrations area that decidedly influences the everyday daily routine and guidelines of experiencing or personal satisfaction. The World Trade Organization (WTO), of which in excess of 156 nations are individuals, has an understanding according to global administrations exchange. The General Agreement on Trade in Services (GATS) is the WTO's arrangement that administers exchange 12 sorts of administrations, including 'instruction administrations'. One of the basic inquiries or issues in such manner would be corresponding to the sort of college to be permitted to set up its grounds or branch or in any case offer training administrations. This paper would endeavor to give some potential experiences into this issue. Internationalization and globalization are the two Global ideas terms conversely utilized as far as higher education. Most impressively, the test to set up colleges will come from the worldwide monsters of the interchanges, data innovation and mixed media ventures worldwide suppliers, packed with capital, ready to get to remarkable global researchers and educators, talented in giving in situ understudy support at the same time in numerous nations, and equipped for expediting proficient accreditation and acknowledgment all throughout the planet. Quality in the subsequent 'worldwide virtual colleges' will be high, normalization will make cost structures that are powerfully serious, brand acknowledgment will be acquired, maybe by accepting one of the incomparable Ivy League organizations as an accomplice, or on the other hand by moving into advanced education a prevailing brand from the correspondences or processing ventures.

Keywords: globalization, advanced education in china, promoting techniques, WTO 


\section{Globalization and Chinese higher education}

\section{Introduction}

China joined the World Trade Organization (WTO) in December 2001. One outcome of the Chinese rising to WTO is the expanded attention to globalization among Chinese higher instructors. "Mix into the world economy has prompted a redefinition of the job of advanced education in China" (Vicovich, Yang, \& Currie, 2007, p. 105). This paper examines the responsibilities than China has made in opening its schooling market in the wake of joining WTO and their plausible effect on Chinese advanced education. The paper additionally portrays Chinese mentalities toward globalization and unfamiliar schooling. At long last it talks about the new improvement in Chinese advanced education concerning worldwide collaboration.

Article II of GATS advances most-supported country treatment, Article XVI desires the opening up of business sectors; Article XVII expects individuals to stretch out public treatment to support providers of any remaining individuals (WTO, 1994). Nonetheless, Clause 1 of Article XIII specifies that Articles II, XVI, and XVII will not have any significant bearing to laws administering the acquisition by administrative organizations of administrations bought for legislative purposes, i.e., those administrations not planned for business resale (Varoglu, 2002).

Clearly, essential and optional instruction in administrations is bought for legislative purposes without the goal of business resale. Paradoxically, advanced education and grown-up training will in general depend more on private wellsprings of financing and are bound to be occupied with business exercises. It follows that higher and grown-up instruction are bound to be viewed as administrations with a view to business resale. Accordingly, it is basically in advanced education and grown-up schooling that legislatures should conclude whether to open their market and how much. The two inquiries are ceaselessly bantered at WTO talks.

With respect to advanced education, there has been a critical upswing in progressions of individuals and administrations past public lines (Vidovich, Yang, \& Currie, 2007). Schooling is being changed and changed into a multi-billion-dollar industry, controlled by market-advancement advocates in the created economies, specifically by in US, the EU, Japan, New Zealand and Australia (Robertson, 2003). In the last round of WTO talks in Hong Kong in December 2005, the US distinguished the progression of advanced education and grown-up schooling administrations as one of its main four needs (Czernis, 2005).

The US needed China to eliminate the disallowance of unfamiliar training administrations gave through satellite innovation and the prerequisite that unfamiliar schooling suppliers should help out Chinese to work in China (Lu \& Zha, 2004). Another multilateral gathering, Friends of Private Education Exports, has framed in New Zealand with its objective to acquire responsibilities from more nations in regards to training administrations (Canadian Association of University Teachers, 2006).

China endeavors to be serious universally and to accomplish "five star" colleges. Two key procedures are decentralization and marketization of advanced education (Vidovich, Yang, \& Currie, 2007). While the Chinese government expresses that China is a communist country at its essential stage, Green (2007) thinks the ascent of China forecasts the making of a totally new type of private enterprise in the biggest market on the planet. Chinese are associated with each of the four global methods of giving instruction administrations (WTO, 2002). With mode one, cross-line administrations, at present some Chinese understudies are getting schooling given by unfamiliar establishments through the Internet.

With mode two, utilization abroad, somewhere in the range of 1978 and 2007 a bigger number of than 1.21 million Chinese traveled to another country to get further schooling. In 2007 alone around 144,000 Chinese went abroad for training (Meng, 2008). In mode three, business presence, somewhere around three Chinese and 
unfamiliar agreeable advanced education foundations have been set up in China (Helms, 2008). With mode four, presence of regular people, more unfamiliar researchers are instructing in China, and an expanding number of Chinese researchers are instructing in different nations.

At the point when China joined WTO and marked GATS, it expressed its position with respect to instruction administrations: (1) China would not open its market in essential and junior optional schooling, and in military and police preparing. (2) Restrictions would not be put on Chinese voyaging abroad for schooling or on unfamiliar nationals entering China for training. (3) With specific conditions, China would slowly open its business sectors for advanced education, grown-up instruction, senior auxiliary training, preschool schooling and other schooling. Unfamiliar organizations would be permitted to help out Chinese however they would not be allowed to work freely in China. (4) When utilized or welcomed by Chinese establishments, unfamiliar teachers would be allowed to work in China (WTO, February 14, 2002). China is the lone country among Economic and Social Commission of Asia and Pacific individuals that has stretched out its responsibilities to change access in every one of the five schooling administrations subsectors (Raychaudhuri \& De, 2007).

The overall point of WTO is to extend global exchange ways that advance monetary development for all part states (WTO, 1994). To extend exchange administrations under states of reformist advancement, GATS advances most-supported country treatment, an open market, and public treatment. As to, this implies that part governments are relied upon to release their power over schooling. Any instructive exercises that charge educational cost can be viewed as exchange administrations.

The utilization WTO rules address a genuine test to the Chinese advanced education framework, which has been under practically complete government control since 1949. Yet, these equivalent guidelines can likewise be seen as a chance that, whenever seized, will work with the change of Chinese advanced education and help to build up a climate in which the advanced education framework can create in manners that better address social issues. There are somewhere around four powers that put focus on the Chinese advanced education framework to change: (1) the expanding interest for advanced education, (2) the financial globalization, (3) the development of private advanced education (Hayhoe \& Lin, 2008), 4) restricted government subsidizing (Dahlman, Zeng, \& Wang, 2007).

Most WTO individuals marked GATS to advance worldwide exchange administrations. Be that as it may, numerous WTO individuals have not explicitly invested in opening their schooling market. After wellbeing, an instructive help is the area where the individuals have set up the least responsibilities on progression (Verger, 2008). As of August 2006, just 39 WTO individuals made a promise to change access their advanced education administrations (Raychaudhuri \& De, 2007). After China made explicit responsibilities to open its market in schooling administrations, more unfamiliar teachers are working in Chinese advanced education. Naikai University in Tianjin began enrolling seat teachers universally in 2004 and senior members of schools and schools in 2006 (Guan, 2006). On May 10, 2007, Austrian physicist Romano A. Rupp showed up as the new Dean of Taida Institute of Applied Physics of Nankai University. Dr. Rupp was an educator at the University of Vienna prior to tolerating the arrangement at (Nankai University, 2007). As the quantity of entomb.

Most WTO individuals marked GATS to advance worldwide exchange administrations. Be that as it may, numerous WTO individuals have not explicitly subscribed to opening their schooling market. After wellbeing, an instructive assistance is the area wherein the individuals have set up the least responsibilities on progression (Verger, 2008). As of August 2006, just 39 WTO individuals made a promise to change access their advanced education administrations (Raychaudhuri \& De, 2007). After China made explicit responsibilities to open its market in schooling administrations, more unfamiliar teachers are working in Chinese advanced education. Naikai University in Tianjin began enrolling seat teachers worldwide in 2004 and senior members of schools and schools in 2006 (Guan, 2006). On May 10, 2007, Austrian physicist Romano A. Rupp showed up as the new Dean of Taida Institute of Applied Physics of Nankai University. Dr. Rupp was an educator at the University of Vienna prior to tolerating the arrangement at (Nankai University, 2007). As the quantity of global researchers 
working in Chinese organizations expands, more worldwide understudies are going to Chinese colleges. As indicated by the Ministry of Education, 162,695 global understudies concentrated in Chinese colleges in 2006, which had an expansion of 15.3 percent more than 2005 .

The three fundamental wellsprings of global understudies were South Korea, Japan, and the United States (Yu, 2007). Most global understudies were self-financed, with around five percent of them on Chinese government grants (Meng, 2006). As globalization advances, worldwide rivalry will surely raise the interest for taught individuals. Since China is expanding its investment in the worldwide economy, it needs accomplished residents who can contend with global associates.

\section{Mentalities toward globalization and foreign education}

Since 1978, China has put itself on course to limit the hole between its advanced education framework and those of created nations. To Chinese instructors, the advantages of additional partaking in worldwide advanced education are as per the following: (1) The Chinese advanced education framework should change its organization to adhere to the applicable WTO rules. These principles will compel the Chinese framework to change a portion of its approaches. (2) The expanded global trades will altogether affect Chinese teacher's practices. They will present new educational models, which may change educational programs locally, broadly, and universally. (3) More private and global financial backers will take part in advanced education. At this point don't will the state be the solitary financial backer. This will steadily ease the issue of insufficient financing. (4) As global trade and collaboration increment and more worldwide schooling assets become accessible to Chinese teachers, they will refresh their insight all the more rapidly.

Simultaneously, China is confronting genuine test a WTO part. Vidovich, Yang, and Currie (2007) contend that the difficulties globalization brings won't be uniform across nations. For Chinese, the first of these difficulties identifies with the likely effect of globalization on the organization of Chinese advanced education. WTO advances the progressive progression of the instruction administrations. As unfamiliar organizations enter China, clashes will emerge identifying with qualities, ideas, and objectives. Right now, the public government settles on the fundamental choices about approach and construction, yet the commonplace governments really manage a significant number of the establishments, which have some independence to address nearby requirements. These will be influenced by GATS. With regards to market influences, Chinese establishments will wind up impeded.

Second, as China goes through progression in administrations, its advanced education establishments will wind up rivaling unfamiliar associations. Since 1999 the quantity of advanced education understudies has nearly significantly increased in China and there are more and bigger colleges, however there are as yet insufficient advanced education foundations, particularly quality ones. A few organizations in created nations have seen this expanding interest for advanced education in China. In 2007 colleges from the United Kingdom, Australia, Canada, France, Germany, Japan, South Korea, New Zealand, Russia, the United States and different nations sent scouts to instructive displays in China or recruited neighborhood agents (China Center for International Educational Exchange, 2008). English and Australian organizations have been especially forceful in enlisting Chinese understudies. To draw in worldwide understudies, a few nations have facilitated their visa prerequisites and surprisingly permitted global understudies to work in their nations. Furthermore, a few foundations in created nations select Chinese specialists by offering more significant compensation and better working conditions. As a result, Chinese foundations may lose a portion of their great educators and scientists. Some top Chinese alumni are billings move to created nations. From 1978 to 2007, of 1.21 million Chinese gone abroad for instruction, just 319,700 have returned (Meng, 2008).

Third, financial globalization and the Internet are creating collaboration, just as clashes, between social orders. It is simpler than any time in recent memory for college understudies to get to a tremendous assortment of societies and thoughts, and this will unequivocally affect their qualities and world perspectives (Dai, n. d.). A

74 Consortia Academia Publishing (A Partner of Tourism Educators and Movers of the Philippines) 
new news report recounts a fruitful Chinese understudy, Wu Yinyin, at Beijing Normal University. Wu is a senior at the college yet she is now the Asia vice president chief of an American organization, Top Coder. She has three good examples: Madame Curie, Mother Teresa, and Hillary Clinton. None of them is Chinese (Gao, 2007).

In 2002 in excess of 700 inhabitants in Beijing, Shanghai, and Guangzhou were overviewed in regards to their perspectives toward unfamiliar schooling after China joined the WTO (National Bureau of Statistics of China, 2002). As for preschool training, by far most (84\%) imagined that homegrown instructive foundations would be sufficient to begin kids' initial schooling. Just a little level of the respondents (16\%) felt that unfamiliar training would help kids prepared themselves before. Concerning long stretches of necessary training (grade one to grade nine), additional respondents (96.5 percent) supported homegrown instruction, and just 3.5 percent figured this piece of schooling ought to be finished in a created country. At the point when it came to senior optional school (grades ten to twelve), 81.5 percent kept on favoring homegrown instruction, however 18.5 percent favored unfamiliar training. The respondents chose the homegrown area in essential and auxiliary schooling on account of the low expenses and the Chinese advanced education passage assessment framework.

At the point when it came to advanced education, homegrown foundations were not appraised exceptionally. The study tracked down that 89.5 percent of the respondents were keen on getting unfamiliar training, and just 10.5 percent chose homegrown foundations. It appeared to be that large numbers of the respondents needed trust in homegrown advanced education. They were not happy with these organizations' objectives, learning climate and business openings. At the point when gotten some information about different preparing programs, 70.5 percent chose unfamiliar schooling, and just 29.5 percent picked homegrown instruction. The accompanying table sums up the respondents' inclinations.

\begin{tabular}{lcc}
\hline & Attitudes toward foreign education survey results in percent & Foreign \\
\hline Pre-school & Domestic & 16 \\
Compulsory & 84 & 3.5 \\
Senior secondary & 96.5 & 18.5 \\
Higher education & 81.5 & 89.5 \\
Training programs & 10.5 & 70.5 \\
\hline
\end{tabular}

At the point when asked what are the upsides of getting unfamiliar instruction, the respondents offered these clarifications: 26.8 percent imagined that unfamiliar schooling would assist understudies with learning thoughts; 25.7 percent trusted that getting unfamiliar training would assist them with creating attractive abilities; 25.7 percent accepted that an unfamiliar instruction would assist them with accomplishing a superior future; 13.4 percent felt that unfamiliar instruction would make them more proficient; and 8.4 percent expected that unfamiliar instruction would make them more adaptable. Concerning, 59.9 percent favored a created country, 7.6 percent would acknowledge global training suppliers working in China, and 32.5 percent believed that either would do (Public Agency of Insights of China, 2002).

Worldwide training trades are empowering Chinese to retain unfamiliar science and innovation just as ongoing advancements in organization. Gaining from created nations is assisting China with fostering its economy just as its science and innovation. It is additionally helping Chinese instructors change and foster their schooling framework (Chen, 2002). In working on the framework, Chinese higher instructors need to think about issues according to a worldwide viewpoint. They should know about WTO guidelines that advance the progression of exchange administrations and make the Chinese advanced education framework more open. They need to investigate freedoms to frame collaboration with global associates (Ge, 2005).

\section{Advancement lately}

One pointer of advanced education improvement is investment rates. At the point when the interest rate in advanced education is between 15\% and 50 percent, it is viewed as mass instruction (Trow, 1973). In 2007 there were in excess of 27 million Chinese understudies in different advanced education programs and the advanced 
education investment rate was 23\% (Service of Schooling, April 2008). The Chinese framework can be viewed as mass instruction. The framework has gotten the biggest on the planet, and advanced education is more available than any other time, however there are sure disadvantages.

There are critical holes in the improvement of advanced education across locales and gatherings of people, just as between metropolitan focuses and country regions. These holes contrarily influence a few families, particularly families in more unfortunate areas, when they attempt to get to advanced education. The support rate doesn't give an exact image of Chinese advanced education. Advanced education isn't accessible in some country and distant regions. With educational cost rising quickly, advanced education is hard for some helpless families to get to. What's more, the expanding accessibility of advanced education is making individuals to focus harder on quality, and there are concerns.

On May 10, 2006, the State Gathering concluded that development in advanced education should have been diminished so monetary assets could zero in additional on further developing the learning climate. This lull will profit establishments as they change disciplines. It will likewise resolve current issues, particularly the issue of work for graduates.

$>$ The in general objective is to make the development in advanced education supportable. The size of the advanced education framework will be balanced out. More consideration will be paid to preparing optional school understudies in abilities that will make them more employable. Grown-up instruction programs, proceeding with training programs, and professional preparing programs in auxiliary schools will all be extended. A few spaces of advanced education will be all the more painstakingly managed. One issue that should be tended to is educational cost climbs; another is foundations' abilities (China Schooling Day by day, 2006). The public authority will improve the nature of advanced education and give more grants and other monetary help (Cui \& Wu, 2008; Wen, 2008).

$>\quad$ The worldwide pattern in advanced education is from tip top schooling to mass, and afterward to widespread training. Issues regularly go with this interaction. In China these issues identify with scale, quality, subsidizing, and structure, just as business openings for graduates. As Chinese advanced education created from world class to mass schooling, the issues identified with the once arranged economy and lacking subsidizing have made the lopsided appropriation of instructive assets extremely self-evident. Chinese are keen on gaining from created nations, and advanced education in China isn't just about as open as in created nations. For these two reasons, among others, China sends a bigger number of understudies abroad for advanced education than some other country. The quantity of Chinese understudies traveling to another country for training is as yet developing. Also, Chinese have begun getting unfamiliar instruction at home.

$>\quad$ On Walk 1, 2003, the State Board proclaimed the Guidelines of Individuals' Republic of China on Chinese-Unfamiliar Collaboration in Running Schools. It expresses that the public government urges Chinese colleges to help out quality unfamiliar training establishments. The public authority especially urges colleges to help out unfamiliar foundations in the fields of organization, money, law, and innovation. As of now, more than 100 Chinese advanced education organizations are helping out American, Australian, English, French, Canadian, Japanese, and German partners to give guidance to Chinese understudies (Service of Schooling, n.d.).

$>\quad$ These Chinese organizations have brought progressed showing assets into Chinese instruction. They have made changes in their regulatory practices, teaching method, and educational plans. The steady opening up of Chinese advanced education permits Chinese instructors to profit with fostered nations' instructive assets. It likewise assists with advancing Chinese schooling in different nations. Before the finish of 2007 there were 210 Confucius foundations in 64 nations all throughout the planet with 46,000 understudies (Liu, 2007). 
$>$ On February 7, 2006, the Service of Schooling reported a declaration as for the collaboration of Chinese and unfamiliar training foundations. This pronouncement guides commonplace schooling services to follow a few standards while teaming up with unfamiliar establishments. In addition to other things, anybody helping out unfamiliar organizations should put the public interest first. Moreover, while working together with unfamiliar organizations, Chinese instructors and heads should keep the applicable laws and guidelines, assume a main part, ensure the interests of all gatherings included, and keep up with public safety, social dependability, and the set up instructive request.

\section{Approach}

The push space of this paper was to inspire and to test the accessible proof for the interest and association of worldwide media in advanced education arrangement. The point is to uncover the proclaimed aims of the significant parts in the field, to test these through interviews with senior agents in important spaces of business, government and instruction, and to attract out the short-to medium-term suggestions for china advanced education. It is significant that the constraints of this examination be perceived. It is consistently conceivable in fact in certain occurrences likely that relevant data may have been retained for business or vital reasons. Business choices, like consolidations, collusions and associations, are not generally unsurprising or predictable, even by those at senior levels in an association. Political and financial choices are similarly not entirely unsurprising. Further, investigation of specialized potential outcomes and probabilities which support the mooted 'globalization of schooling' was past the extent of this examination.

The remarks in this space are essentially expansive brush. The outcomes ought to subsequently be deciphered as an accessible 'proof keep an eye on' the expansive situations that have been advanced by different analysts in the contemporary advanced education banter. The examination ought to likewise be recognized from the proposition of long haul liked Fates. It is grounded in contemporary turns of events and educated extrapolation from them, and doesn't indicate to offer perspectives on what may be helpful long haul Future frameworks of advanced education, in china or worldwide settings.

In September 2004, the principal understudies entered the grounds of the College of Nottingham Ningbo, is the main college planned, assembled, and run agreeably by Chinese and an unfamiliar college. The Chancellor of Nottingham College in Britain, Yang Fujia, is the leader of Nottingham-Ningbo, and Ian Gleam, previous Head of Nottingham College Business college, is the VP. The College of Nottingham Ningbo follows the educational plan and assessment methods of Nottingham College in Britain, which chooses teachers for Nottingham-Ningbo. Guidance is given in English. The permit to work the College of Nottingham-Ningbo is legitimate until 2055 (Service of Schooling, September 5, 2007). On graduation, understudies will be presented a Chinese undergrad graduation endorsement and a four-year certification from Nottingham College. In September 2006, the principal understudies began their investigation at Xi'an Jiaotong Liverpool College in Suzhou, which is a joint endeavor of Xi'an Jiaotong College and the College of Liverpool. The permit of Xi'an Jiao tong-Liverpool College is legitimate to 2056 (Service of Instruction, September 5, 2007; Xi'an Jiao tong College, 2008).

China has gone through a colossal change since it fired opening up in 1978. The economy has been totally changed, and subsequently the Chinese work market is going through significant changes. To meet the prerequisites of the changing work market, Chinese higher teachers think about the equilibrium of organic market when they plan educational program. Chinese higher teachers have been focusing harder on cultural change, and contrasted and the past, the public government has given significant self-rule to colleges (Yang, Voinovich, \& Currie, 2007).

On July 12, 2006, the Third Worldwide Chinese and Unfamiliar College Presidents' Discussion was held in Shanghai. College presidents from the US, England, Canada, Australia, Japan, and different nations went to the gathering to examine how colleges can all the more likely serve monetary and social turn of events. The Chinese Priest of Instruction, Zhou Ji, met with a portion of the unfamiliar college presidents in participation, affirmed 
that global collaboration was emphatically affecting Chinese schooling, and urged his visitors to reinforce their participation with Chinese partners (Service of Training, July 14, 2006). On April 6, 2007, the Service of Training proclaimed a declaration to give more itemized rules to participation among Chinese and unfamiliar advanced education establishments.

In 2007 about 10.1 million Chinese applied to take the advanced education passage assessments, with an expansion of 0.6 million more than 2006. On June 7 and 8, 2007, 9.5 million individuals really took the assessments (Yang, 2007). About 5.7 million individuals were conceded into different advanced education programs in the fall (Service of Instruction, April 2008). As interest for advanced education increments, so does the interest in going abroad for training. On June 16, 2007, Beijing 21st Century Trial School declared that it would open an American Progressed Situation Program in the fall. Inside a few days more than 200 individuals had counseled the school, and in excess of 60 auxiliary school understudies had applied (Tooth \& Li, 2007). Those keen on the program proposed to go to concentrate in an American college. In Nanjing, Nanjing Unknown Dialect School will concede 150 understudies into its "Sino-Canada Worldwide Senior Auxiliary Program" in the fall. The latest 75 alumni from this program have all been conceded into colleges in the US, Canada, and other English talking nations (Chen, 2008).

\subsection{Extent of the examination}

The discoveries and finishes of the current examination will be useful to direct different nations in reading the ramifications for the advanced education under GATs

\section{Conclusion}

Globalization is affecting Chinese advanced education. It has brought genuine freedoms just as genuine difficulties. Across the world the interest for worldwide instruction is figure to expand (Raychaudhuri \& De, 2007). There is a colossal craving for advanced education in thickly populated nations that need to construct human resources to completely partake in the information society (Knight, 2006). In spite of the fact that there are questions and various feelings (Healey, 2007), internationalization is a good and inescapable component of worldwide advanced education (Altbach, 2008a). Globalization - comprehended as the quick speed increase of cross-line streams of capital, individuals, administrations, merchandise, and thoughts - is the characterizing highlight of our age (Green, 2007). Chinese training strategies and administration have been impacted by globalization plans and worldwide patterns (Mok, 2007). While Altbach (2008b) thinks globalization has not prompted uniformity in advanced education, we think keeping the applicable WTO rules is helpful for the improvement of Chinese advanced education. In the discussion about potential effects from globalization, most Chinese researchers figure they will affect Chinese advanced education (Chen, 2002; Dai, n.d.; Ge, 2005; Guan, 2006; Meng, 2006; Vidovich, Yang, \& Currie, 2007; Wu 2002). Chinese are keen on gaining from created nations, the strategy first class in China has effectively and excitedly drew in with globalization, the Chinese interest for advanced education keeps on developing, unfamiliar suppliers are satisfying aspect of this need, and market belief systems might be a more grounded impact in Chinese advanced education (Yang, Vidovich, \& Currie 2007). Signs are that in taking advantage of lucky breaks and managing difficulties, most Chinese higher instructors are keen on globalization and will extend their collaboration with worldwide partners to meet the changing and expanding needs of society.

\section{References}

Altbach, P. (2008a). The "subprime" market and global advanced education. Worldwide Higher Education, 51. http://www.bc.edu/bc_org/avp/soe/cihe/pamphlet/Number51/p2_Altbach.htm

Altbach, P. (2008b). Globalization and powers for change in advanced education. Worldwide Advanced Education, 50. http://www.bc.edu/bc_org/avp/soe/cihe/pamphlet/Number50/p2_Altbach.htm

Canadian Relationship of College Educators. (2006, January). Instruction designated in WTO talks. CAUT

78 Consortia Academia Publishing (A Partner of Tourism Educators and Movers of the Philippines) 


\section{Release, A1.}

Chen, K. (2008). Nanwai "zhongjia guoji gaozhong" zhaosheng 150 ren [Nanjing Foreign Language School will concede 150 understudies into their "Sino-Canada International Senior Auxiliary Program"].

Chen, Z. (2002). Woguo jiaru WTO dui jiaoyu de yingxiang ji duice [Joining WTO's effect on instruction and our strategies]. China Training Day by day, January $9,1$.

China Community for Worldwide Instructive Trade. (2008). 2007 exhibitor list. http://www.chinaeducationexpo.com/english/presentation/2007previous_event.html

China Instruction Every day. (2006). May 11, 1.

Cui, J., \& Wu, J. (2008, Walk 15). China advances by and large instructive value. Individuals' Day by day Abroad Release, 4.

Czernis, L. (2005, December). Advanced education not for exchange. CAUT Notice, A3.

Tooth, C., \& Li, Y. (2007, June 28). For what reason would they say they are keen on American colleges? Individuals' Everyday Abroad Release, 4.

Gao, R. (2007, July 18). Wu Yinyin: A day to day existence brimming with contests. Individuals' Everyday Overseas Version, 7.

Ge, L. (2005). WTO уи jiaоyи guоjihua de sikao [WTO and the internationalization of Chinese education]. http://www.ep-china.net/article/key/2005/07/20050718201714.htm

Green, A. (2007). Globalization and the changing idea of the state in East Asia. Globalization, Social orders and Instruction, 5(1), 23-38.

Hayhoe, R., \& Lin, J. (2008). China's private colleges: An effective case study. Worldwide Advanced Education, 51. http://www.bc.edu/bc_org/avp/soe/cihe/pamphlet/Number51/p6_Hayhoe_Lin.htm

Healey, N. (2007). Is advanced education in truly "internationalizing"? High Schooling, 55, 333-355.

Steerages, R. (2008). Transnational schooling in China: Major questions, basic issues and strategies for progress. The Observatory on Borderless Advanced education. http://www.obhe.ac.uk/items/reports/

Liu, F. (2007, December 10). Confucius organizations spread across the world. Individuals' Daily Abroad Release, 1.

Meng, Z. (2008, June 26). 30 years of understudies going abroad. Individuals' Everyday Overseas Release, 6. Service of Instruction. (n.d.). Bufen zhongwai hezuo banxue jigou he xiangmu xiangguan xinxi [Information on Chinese and unfamiliar co-employable organizations and programs (preliminary)]. http://www.moe.gov.cn/edoas/website18/top_zwhzbx.jsp

Mok, K. H. (2007). Globalization, new schooling administration and state limit in East Asia. Globalization, Social orders and Instruction, 5(1), 1-21.

Nankai College. (2007). Nankai daxue shouwei waiguo yuanzhang daoren [First foreign dignitary showed up at Nankai]. http://user.nankai.edu.cn/WSW/Bar/Content.aspx?ID=827

Public Agency of Insights of China. (2002). 89.5\% de ren qingxin waiguo gaodeng jiaoyu [89.5\% Respondents Intrigued by Unfamiliar Higher Education]. http://www.stats.gov.cn/tjfx/rddc/t20020531_21041.htm

Robertson, S. (2003). WTO/GATS and the worldwide instruction administrations industry. Globalization, Social Orders and Schooling, 1(3), 259-266.

State Gathering. (2003). The guidelines of individuals' Republic of China on Chinese foreign co-activity in running schools. http://www.moe.edu.cn/english/laws_r.htm

Trow, M. (1973). Issues in the change from tip top to mass advanced education. New York: Carnegie Commission on Advanced education.

Verger, A. (2008). Estimating instructive advancement. A worldwide examination of GATS. Globalization, Social orders and Training, 6(1), 13-31.

Vidovich, L., Yang, R., \& Currie, J. (2007). Changing accountabilities in higher education as China "opens up" to globalization. Globalization, Social Orders and Education, 5(1), 89-107.

Wen, J. (2008, Walk 6). A report of the public authority's work. Individuals' Day by day Overseas Version, 3.

WTO. (1991). Administrations sectoral grouping list. http://www.wto.org/english/tratop_e/serv_e/mtn_gns_w_120_e.doc

WTO. (1994). General concession to exchange administrations. 
Kamala, K., \& Kamalakar, G.

http://www.wto.org/english/docs_e/legal_e/26-gats_01_e.htm\#articleXIII

WTO. (2002, February 14). GATS/SC/135 (02-0796), Exchange administrations, The People's Republic of China, Timetable of explicit responsibilities.

http://www.wto.org/english/tratop_e/serv_e/serv_commitments_e.htm

WTO. (2006). Understanding the WTO: Essentials. https://wto.org/english/thewto_e/whatis_e/tif_e/fact2_e.htm

Xi'an Jiaotong College. (2008). Xijiao liwupu daxue [Xi'an Jiaotong-Liverpool University]. http://www.xjtu.edu.cn/hzjl/xjlwpdx.html

Yang, M. (2007, May 29). The current year's advanced education section assessments made two new records. Individuals' Everyday Abroad Release, 1.

Yu, J. (2007, May 29). Last year more than 160,000 global understudies contemplated in China. Individuals' Everyday Abroad Release. 